\title{
Dijital Ekonominin Katma Değer Vergisi Açısından Değerlendirilmesi
}

\author{
Onur EROĞLU* $\quad$ Hüseyin AKSU**
}

\begin{abstract}
$\ddot{O} Z$
Internet üzerinden kazanç elde etme yolları yıllar içinde çeşitlenmiş, bununla beraber klasik anlamda bilinen bir kısım kazanç elde etme yöntemleri dijital ortama taşınmıştır. Hatta internet ortamının sunduğu geniş imkânlar yeni kazanç yöntemlerini ortaya çıkarmışıtır. Dijital ortamda ortaya çıkan yeni kazanç yolları ise daha çok "hizmet ifası" olarak kendini göstermektedir. Çünkü internet sunduğu çok düşük sabit maliyet avantajı ile hizmet bazlı pek çok girişimin hayata geçmesini sağlamıştır.

Elektronik ortamda vücut bulan söz konusu kazanç yöntemleri bir bütün halinde dijital ekonomi kavramını ortaya çıkarmıştır. Ancak giderek devleşen dijital ekonomi, klasik anlamdaki ekonomik işlemler için hazırlanmış mali mevzuatta tam olarak karşıllk bulamamıştır. Verginin tarh ve beyan edilmesi gereken yer, mükellefiyet, vergi sorumlusu gibi başlıca hususlart ile Katma Değer Vergisi Kanunu, dijital ekonomide sorunlar yaşanan alanlardan biri olarak karşımıza çıkmıştır.

Bu çalışmada, ilk olarak dijital ekonomi kavramına değinildikten sonra ikinci bölümde dijital mal ve hizmetlerin vergisel yönüne yer verilmiştir. Son bölümde ise Katma Değer Vergisi açısından dijital ekonomi ele alınarak, vergi mevzuatında gerçekleştirilen değişiklikler değerlendirilmiştir.
\end{abstract}

Anahtar Kelimeler: Dijital Ekonomi, Vergilendirme, Katma Değer Vergisi

JEL Sinıflandirması: K34, H25, H26

\section{Evaluation of Value Added Tax İn Terms Of Digital Economy}

\begin{abstract}
The ways of earning on the internet have diversified over the years, and some methods of earning profits known in the classical sense have been carried out in digital environment. In fact, the wide range of possibilities offered by the internet environment reveals new ways of earning. New ways of generating income in the digital environment are more like "service performance". Because of the very low fixed cost advantage offered by the internet, many service-based entrepreneurs have made it happen.

The methods of profit taking in electronic environment reveal the concept of digital economy as a whole. However, the digital economy, which has become increasingly mature, has not found a full response to the fiscal legislation prepared for economic transactions in the classical sense. The main points such as the place where the tax is to be declared and declared, liability, tax accountability and the Value Added Tax Law are confronted as one of the areas experiencing problems in the digital economy.

In this study, firstly the concept of digital economy is mentioned, and in the second part, the tax aspects of digital goods and services are given. In the last section, the digital economy is evaluated in terms of Value Added Tax and the changes made in tax legislation are evaluated.
\end{abstract}

Keywords: Digital Economy, Taxation, Value Added Tax

JEL Classification: K34, H25, H26

\footnotetext{
* Doç. Dr. Zonguldak Bülent Ecevit Üniversitesi, İ̈BF, Maliye Bölümü. onur_eroglu@beun.edu.tr

${ }^{* *}$ Zonguldak Bülent Ecevit Üniversitesi, SBE, Maliye Tezli Yüksek Lisans Öğrencisi, huseyinaksu.z@hotmail.com
} 


\section{GíRIŞ}

Bilgi ve işlem teknolojilerinde yaşanan gelişme ile internet kullanım amacı pazarlama ve ekonomiyi de kapsamına almıştır. İnternet ve erişimi mümkün kılan nesnelerin ucuzlaması ile dünyanın herhangi bir yerinden farklı bir noktasına ulaşım imkânı doğmuștur. Klasik mal ve hizmetlerin yanı sıra dijital mal ve hizmetlerin ortaya çıkması ve bunların elektronik ortamlarda internet aracılığıyla pazarlanabilmeleri ile dijital ekonomi kavramı ortaya çıkmıştır.

Tahmin edilebileceği üzere kavram olarak tanımı yapıldığında dahi soyut anlamlar içeren ekonomik bir sistemin, mali idarelerce takip edilmesi ve denetlenmesi henüz aşılamamış güçlükler içermektedir. Nitekim internet ülkelerin siyasi ve fiziki sınırlarını aşan dijital bir platformdur. Söz konusu network ağının fiziki sınırlara bölünememesi, hükümetlerin vergilendirme için mukimlik, mükellefiyet tesisi ve vergi sorumlusu konularında sorunlar yaşamasına neden olmuştur.

Çalışmanın ilk bölümün dijital ekonomi kavramı açıklanacak ve daha sonra ikinci bölümde katma değer vergisinin ilgilendiren dijital mal ve hizmetlerin vergisel yönü ele alınacaktır. Üçüncü bölümde ise katma değer vergisi açısından dijital ekonominin getirdiği vergilendirme sorunları, bu sorunlara yönelik gerçekleştirilen uluslararası çalışmalar ve ülkemiz katma değer vergisi uygulamasında, bu çalışmalar doğrultusunda atılan adımlar ve düzenlemeler değerlendirilecektir.

\section{DİJITAL EKONOMI}

Dijital ekonomi, teknolojiyi daha ucuz, daha güçlü ve yaygın bir şekilde standart hale getiren, iş sürecini iyileştiren ve ekonominin tüm sektörlerinde yeniliği destekleyen bilgi ve iletişim teknolojisinin getirdiği dönüşüm sürecinin sonucunda oluşan ekonomidir (OECD, 2015:11). Daha kısa bir tanımla, klasik üretim sistemlerine yeni iletişim ve bilgi teknolojilerinin uyarlanması sonucunda oluşan ekonomi olarak ifade edilebilir (Bayraç, 2003:49).

Dijital ekonominin, potansiyel vergiyle ilgili öne çıkan bir dizi özelliği bulunmaktadır. Bu özellikler dijital ekonominin her bir iş alanında aynı anda var olmayabilir, ancak giderek artan dijital ekonomiyi ayırt edici unsurları belirtmektedir. Dijital ekonomiyi karakterize eden bu temel özellikler; hareketlilik, verilere güven, kullanıcı katılımı, entegrasyon ve sinerji ile anlaşılan ağ etkileri, pazarın iki tarafının da farklı vergilendirme bölgelerinde olabileceği çok taraflı iş modellerinin kullanılması, büyük ölçüde ağ etkilerine dayanan belirli iş modellerinde tekel veya oligopole eğilim, azalan giriş engelleri ve hızla gelişen teknolojinin neden olduğu değişkenlik olarak belirtilebilir. Dijital ekonominin bu özellikleri ile ulusal pazarların geleneksel sınırları büyük ölçüde ortadan kalkmaktadır. $\mathrm{Bu}$ gelişmelere paralel olarak ulusal otoriteler, özellikle dijital ürünlerde vergilendirme işlevini yitirmektedir (World Bank, 2016:64-65).

Dijital ekonomi; elektronik ticaret, online uygulama mağazaları, web tabanlı reklamcılık, bulut bilişim, üç boyutlu baskı, sanal para kullanımı gibi faaliyetlerin tümünü kapsamaktadır (Özcan, 2016:74). Bu faaliyetlerin dijital ekonominin barındırdığı özelliklerle vergisel riskler doğurduğu ve ülkelerin vergi 
gelirlerinde aşınmalara neden olduğu görülmektedir (OECD, 2015:55). Dolayısıyla ülkelerin vergi gelirlerinde önemli yeri olan KDV açısından dijital ekonominin getirdiği vergilendirme sorunları ve bu sorunlara yönelik gerçekleştirilen düzenlemeler önem kazanmaktadır.

\section{DİJITAL MAL VE HİZMETLERIN VERGISSEL YÖNÜ}

Dijital ekonominin hacmi ve kapsamındaki faaliyetler, bilgi ve işlem teknolojilerindeki gelişmelerle birlikte hızla büyümektedir. Bu durum beraberinde yeni iş yapma biçimlerini ve daha öncesinde tahmin edilemeyen yeni dijital ürünlerin oluşumunu getirmektedir. Geleneksel işletmelerin ürettiği geliri ve katma değeri vergilendirmek üzere düzenlenen standart vergilendirme çerçevesi, dijital ekonominin getirdiği yeni iş modellerini vergilendirmekte zorluklarla karşılaşmaktadır (Charrié ve Janin, 2015:1). Özellikle ulusal sınırların öneminin yitirilmesi devletlerin vergilendirme yetkisinin aşınmasına, uluslararası platformda dijital mal ve hizmetlerin sunumu ile gerçekleştirilen faaliyetler dolayısıyla vergilendirilemeyen bir taban oluşmasına neden olmaktadır (Coşkun, 2005:153).

Dijital ekonomi ile herhangi bir ülke hukukuna tabi olmayan işletmeler ortaya çıkmıştır. Bununla birlikte maddi olmayan varlıkların hareketliliğinin ve kullanımının artması ile önemli ekonomik değer zincirlerinin farklı yarg1 bölgelerine online platformlar aracılığıly transferinin mümkün hale gelmesi ve bunların takip edilmesindeki güçlük ulusal vergi otoritelerinin zorlanmasına yol açmaktadır (Belleflamme ve Toulemonde, 2016:11).

Buna ek olarak, geleneksel ticaret biçimlerinden uzaklaşma, vergi otoritelerinin satış ve finansal işlemlere dayalı olarak vergi toplayabilme yeteneğini azaltarak, mali gelirlerinde düşüşe neden olmaktadır (Stratégie, 2015:15). Yaşanan bu durumlar, vergi sisteminin bütünlüğünü zayıflatmakta ve potansiyel gelir hedeflerine ulaşma zorluğunu artırmaktadır (OECD, 2015:78).

Dijital ekonomin ortaya çıkardığı risklerden bir diğerini de vergilendirme yetkisine sahip idarelerin tespiti konusu oluşturmaktadır. Geçerli uluslararası kurallar uyarınca, bir e-terzi tarafından yapılan uzaktan hizmet sunumu vergiye tabi varlık oluşturmaz, buna karşllık bağımsız bir sunucu gibi bir varlığın varlığ 1 söz konusu olduğunda vergilendirme yerinin tespitini kolaylaştırdığından yapılan hizmet sunumu/satışın vergilendirilmesi söz konusu olabilir. Bunun yanında, evde ve işyerlerinde yaygın olarak kullanılma kapasitesine sahip olan 3D baskı teknolojilerinin yoğun olarak kullanılmaya başlamasıyla vergilendirme yetkisine sahip idarelerin tespiti daha da zorlaşabilmektedir (Elele, 2016). Dolayısıyla daimî işyeri kavramı veya uygulaması herhangi bir fiziksel varlığa gereksinim duymayan bir web mağazasına sahip dijital işletmelerde söz konusu olmamaktadır. Dijitalleşme ile birlikte daha rahat ulaşılan açık pazarlar, maddi olmayan varlıklar, işletmelerin yerel düzeyde herhangi bir hukuki veya fiziksel varlığa ihtiyaç duymadan pazar paylarını artırmalarını ve vergi dışı kârlar elde etmelerini kolaylaştırmaktadır (Olbert ve Spengel, 2017). 


\section{A. Uluslararası Platformda Gerçekleştirilen Baş̧ıca Dijital Hizmetler}

Dijital mal teslimi ve hizmet ifası ile bunların alım satımı esnasında her aşamada alınan bir vergi olan KDV açısından değerlendirme yapabilmek için öncelikle dijital ürün ve hizmetlere de kısaca değinmek gerekmektedir (Ertaş, 2017b).

\section{Hosting Hizmetleri}

Hosting, web sitesi verilerinin internet ortamındaki büyük veri yığınına dahil edilmek üzere server (sunucu) denilen yüksek bellek kapasiteli bilgisayarlarda depolanması hizmetidir. Domain ise web sitelerinin internet ağında çağrılmasını sağlayan internet protokol numarası içeren adlardır (Kızıl, 2016:110).

Domain firmaları server bilgisayarlarını şirket merkezlerinin bulunduğu ülkelerde tutabildiği gibi farklı ülkelerde de tutabilmektedir. Bununla beraber hosting hizmeti almak için yapılan tüm işlemler internet üzerinden yürümektedir. Böylece hosting hizmeti almak isteyen kişi dünyanın herhangi bir yerindeki şirketten hosting hizmeti alabilmektedir (Ertaş, 2017a). Dolayısıyla ilgili ülke vergi mevzuatına göre herhangi bir bağı bulunmayan yurtdışı işletmeler tarafindan sunulan hizmetlerin vergilendirilmesinde vergi mükellef ve sorumlusunun tespitinde belirsizlikler oluşabilecektir.

\section{Dijital Reklamcılık Hizmetleri}

Online uygulamalarda ve web sitelerinde yazı, görüntü, ses, animasyon gibi araçların kullanıldığ 1 online pazarlama içerisinde yer alan reklamlara dijital reklamlar denilmektedir (Özen ve Sarı, 2008:15). İnternet reklamcıllı̆ı, online reklamcilık gibi adlarla da nitelendirilen dijital reklamcilık ilk kez 1994'te Hotwired.com üzerinde banner reklamların gösterilmesi ile gerçekleşmiştir (Aktaş, 2010:151). Reklam sektörünün geleceğini önemli ölçüde değiştirecek bu keşifle birlikte, büyük yayınevleri ve dijital platformu yatırım aracı olarak görenler web üzerinden yapılan reklamların daha profesyonel şekilde kullanılabilmesi amacına odaklanmışlardır. Web sayfalarını içerdikleri asıl bilgiye ek olarak çeşitli mesajlara da yer verebilecek bir ortam olarak görmeye başlamışlardır. İnternet erişimini kolaylaştıran nesnelerin artışı ile beraber web sayfalarının sayısının artması reklamcılık sektörü için dijital ortamda yeni bir pazar ortaya çıkmasına neden olmuştur (Özen ve Sarı, 2008:16).

Vergilendirme açısından bakıldığında ise, web siteleri aracılı̆̆ıyla reklam geliri elde eden işletmelerin sunucu bilgisayarlarını farklı ülkelerde konumlandırarak işlemlerini yönetebilmesi, kaynak ülkenin vergilendirme yetkisini yitirmesine neden olmaktadır (Coşkun, 2005:154). Ayrıca web tabanlı reklamcılık ile uğraşan işletmeler sundukları hizmetlerin katma değer vergisi mükellefi olmalarına rağmen, ilgili ülke nezdinde mükellefiyetlerinin bulunmaması ve müşterilerin nihai tüketicilerden oluşması durumunda verginin tarh ve tahsilinde sorunlar oluşabilmektedir (Alptürk, 2009).

\section{Serbest Çalışanlar Tarafından Sunulan Hizmetler}

Freelance hizmet olarakta bilinen bu hizmetler, herhangi bir işverene bağlı olmadan kendisinden iş talep edilmesi halinde sunulan hizmetleri ifade etmektedir (Ertaş, 2017a). Online platformlar aracılığıyla sunulan bu freelance hizmetler çok 
çeşitli şekillerde olabilmektedir. Ancak bu hizmetlerin öne çıkanları; web yazılımı, arama motoru optimizasyonu, web tasatım, grafik tasarım ve yabancı dil çevirisidir (Elele, 2018). Söz konusu hizmetler, freelance olarak tabir edilen bir kişi tarafından, bir kuruma ya da işverene bağlı olmaksızın çoğunlukla evden, kendi kișisel imkanları ile sunulmaktadır. Bu hizmetleri sunanlar ve talep edenler birbirlerine bu hizmetlere yönelik oluşturulmuş web siteleri aracilığıla fiziki olarak bir araya gelmeden ulaşabilmektedirler (Eralp, 2018). Dolayısıyla bu hizmet türünde de dünyanın herhangi bir yerindeki herhangi bir kişiden ücreti mukabilinde hizmet sunumu gerçekleştirilebileceğinden, bu hizmetlerin sunumundan doğan katma değer vergisi mükellefiyeti ve sorumlusunun tespitinde güçlükler oluşabilecektir.

\section{Dijital Öğrenim Hizmetleri}

Online öğrenme hizmeti, freelance hizmet siteleri üzerinden alınabileceği gibi başlı başına bu hizmeti sunan yabancı eğitim kurumlarından da alınabilmektedir. Söz konusu elektronik eğitim kurumları web siteleri üzerinden dünyanın her tarafına online eğitim setlerini satabilmekte ve hizmet sunumunu gerçekleştirebilmektedirler (Ertaş, 2017a:134). Serbest çalışanlar tarafindan sunulan hizmetlerde oluşan vergilendirme sorunları bu hizmet türünde de katma değeri vergilendirmede benzer güçlükler oluşturmaktadır.

\section{B. Hizmetin Tarafları}

Dijital mal ve hizmetlerin sunumu işleme taraf olanlar açısından ele alındığında elektronik ticarette olduğu gibi dört farklı şekilde ele alınabilmektedir. Bunlar; İşletmeden İşletmeye (B2B), İşletmeden Tüketiciye (B2C), Tüketiciden Tüketiciye (C2C) ve Tüketiciden İşletmeye (C2B) sunulan hizmetler olarak olarak belirtilebilir (Ertaş, 2017a:134; OECD, 2015:55).

Işsetmeden tüketiciye (B2C), sunulan faaliyet türünde perakende ürün ve hizmet satışı nihai tüketicilere yapılır. Burada ürün ve hizmete örnek olarak, somut sayılabilecek ürünlerin yanında, yazılım, indirim kuponu, dijital reklamcılık, eğitim ve seyahat hizmetleri vardır.

Işletmeden işletmeye (B2B), işletmeler arası işlemleri ifade etmektedir. Burada üretici ile toptancı işletme arasında veya işletmelerin tedarik pazarlamasının oluşturulması, reklam çalışmalarının takip ve stratejisi gibi işlemler yer alır.

Bu faaliyet türlerinden B2B kapsamında gerçekleştirilenlerin işletmelerce kayıt altına alınması denetimini ve vergilendirilmesini kolaylaştırmaktadır. Ancak B2C, C2C türlerinde hizmeti alanlar potansiyel mükellefler olduğu için bunların ilgili ülke vergi otoritelerince birer birer belirlenmesi ve takip edilmesi mümkün olmayacaktır (Ertaş, 2017a:134). Ayrıca C2B ve C2C modellerinde kendilerine ait bir şirket olmadan hizmet sunumu gerçekleştiren şahıslardan alınan hizmetlerde faturalandırma sorunu oluşacaktır. Dolaysıyla dijital ortamda hizmet alımı konusunda asıl problemi nihai tüketicinin internet üzerinden aldığı ve sunduğu hizmetler oluşturmaktadır (Ertaş, 2017a:134). 


\section{KATMA DEĞER VERGISII AÇISINDAN DİJITAL EKONOMIYE BAKIŞ}

Mal ve hizmet sunumunun dijital ortamda gerçekleştirilebilmesi ile vergilendirme açısından değerlendirilmesi ihtiyacı doğmuştur. Fiziki varlığa sahip olup dijital platformlar aracılığıyla sunulan mallarda katma değer vergisi açısından mevcut kurallar yeterliliğini korumaktayken, dijital olarak sunulan mal ve hizmetlerin tedarik aşamalarının kavranması ve vergilendirmesinde mevcut katma değer vergisi kuralları yetersiz kalmaktadır. Yurt dışından sunulan hizmetlerin ticari faaliyet kapsamında yapılması halinde, hizmetten faydalananların sorumlu sıfatıyla KDV'ni yapacakları ödemeden tevkif ederek indirim imkanına sahip olmaları, bu tarz işlemlerde karşılaşılan sorunları azaltmaktadır. Fakat hizmetin sunulduğu kişi gerçek kişiler olduğunda KDV açısından sorumlu olan bu kişilerin sorumluluklarını yerine getirmedikleri ve sorunlara neden oldukları görülmektedir. $\mathrm{Bu}$ sorunun ana nedenleri; mükellefiyet tesis ettirme ve beyanname verme koşullarının zor olması, ödeyecekleri katma değer vergisini indirim mekanizmasından faydalanarak indiremeyecekleri için aldıkları hizmetin maliyetini arttırması, tespitinin ve denetim geçirme ihtimalinin çok az olması gibi durumlardan oluşmaktadır. $\mathrm{Bu}$ nedenlerle birlikte dijital ekonomi ile nihai tüketicilere yani gerçek kişilere sunulan mal ve hizmetlerin artması, KDV açısından yaşanan gelir kaybının giderek artacağı anlamına gelmektedir (Nazali, 2018).

Bunlara ek olarak, dijital ürünlerin niteliğinin belirlenememesi yani ürünlerin karakterinin hizmet olarak m1, yoksa mal olarak $\mathrm{m} 1$ değerlendirileceği, gayri maddi hak kapsamına girip girmeyeceğinin tespit edilmesi, bu ürünlerin satışından elde edilecek gelirin hangi kazanç kapsamına gireceği konusunda da sorun oluşturmaktadır. Dolayısıyla ne şekilde vergilendirileceğini bilinmeyen ve tespiti zor olan bir alım satım işleminde elde edilen katma değerin vergilendirilmesi güçleşmektedir.

\section{A. Hizmetlerin Vergilendirilme Yeri}

Katma değer vergisinin uygulanmasında temel alınan ilkelerden biri varış yerinde (destinasyon ilkesi) vergilendirmedir. $\mathrm{Bu}$ ilke doğrultusunda, yurtdış1 işleme tabi olan mal ve hizmetler varış ülkesinde vergilendirilirken, söz konusu hizmetlerin çıkışının yapıldığı ülkede vergiden istisna edilmektedir (OECD, 2017:15).

Dijital ekonomi açısından sorun oluşturan tüketicilere yönelik hizmet ve maddi olmayan varlıklar için vergilendirme yerinin belirlenmesine yönelik ise OECD iki genel kuralı tavsiye etmektedir (OECD, 2017:66):

- Fiziksel olarak kolayca tanımlanabilir bir yerde ifa edilen ve hem hizmet tedarikini gerçekleştiren kişinin hem de hizmetten faydalanan kişinin aynı yerde bulunmaları durumunda, hizmetin sunulduğu yerde kullanılan ve faydalanılan hizmetler tedarik yerinde (ifa yerinde) vergilendirilirler.

- Yurtdışı işletmeler tarafından nihai tüketiciye sunulan ve konum bağlantısı olmayan hizmetlerde ise, hizmetten faydalanan müşterinin ikametgahı referans alınarak ilgili ülkede katma değer vergisine tabi olması önerilmektedir. 
İnternet aracılı̆̆ıyla sunulan yazılım, finansman, hukuk hizmetleri gibi dijital içeriklerden oluşan hizmetler örnek verilebilir.

Dijital hizmet ve gayri maddi varlıkların sunumunda da hizmet tedarikini gerçekleştiren ile hizmetten faydalanan müşterilerin farklı konumlar olmaları ve işlemlerin asgari düzeyde bilgi ile gerçekleştirilebilmesi vergilendirmenin yapılacağı ikametgahın tespitini güçleştirmektedir (Nazali, 2018).

\section{B. Uluslararası Platformda KDV Sorunu ve Yapılan Düzenlemeler}

Katma değerin vergilendirilmesinde temel alınan işlemi gerçekleştiren kişinin bulunduğu yer ve hizmetten faydalanılan yer ilkeleri dijital ekonomi kapsamındaki mal ve hizmetlerden doğan katma değeri vergilendirmede yetersiz kalabilmektedir. Şöyle ki gerçekleştirilen işlemlere taraf olanların tespiti ve sunulan hizmetin niteliği mevcut vergi kurallarına göre belirlenmesi çok maliyetli olmakta hatta mümkün olmamaktadır. Dolayısıyla yerleşik olmayan yurtdışı işletmeler tarafindan sağlanan dijital mal ve hizmet tedarikleri teknik açıdan sorun oluşturmaktadır (Organ ve Çavdar, 2012:70). İşlemlerin nerede yapıldığı, işlemin türü, işleme taraf olanların mükellefiyet durumları gibi konularda açıklık olmadığından gerçekleşen işlemler nedeniyle KDV'nin tarh ve tahsili de güçleşmektedir (Alptürk, 2005:328).

Ekim 1998 döneminde, OECD üye ülke bakanları tarafından gerçekleştirilen Ottawa Konferansı'nda ${ }^{1}$ belirlenen vergilendirmeye yönelik birtakım tedbir ve öneriler doğrultusunda; katma değer vergisinin mal ve hizmetin tüketimin yapıldığı yerde tahakkuk ettirileceği ve gümrük vergileri ile katma değer vergisi açısından dijital ürünlerin fiziki mal olarak kabul edilemeyeceği belirtilmiştir (Alptürk, 2009). Ancak fiziki malların tesliminin tersine, dijital ürünlerin tesliminde gümrükten geçmek söz konusu olmadığ 1 gibi işlemin gözle görülür bir belirtisinin de bulunmaması dijital mal ve hizmetlere yönelik katma değer vergisi uygulaması usul ve esaslarının tam olarak ortaya konulamadığını göstermektedir (Coşkun, 2005:153).

Dijital ekonomide yaşanan gelişmeler ve sorunlar daha sonra OECD tarafından 2015 yılında hazırlanan Matrah Aşındırma ve Kar Aktarımı Eylem Planı'nda (BEPS) üç başlık altında kategorize edilerek sistemsel zorluklar veya diğer bir deyişle daha kapsamlı vergileme zorlukları olarak ortaya konulmuştur (OECD, 2015):

- Nihai tüketicinin bulunduğu ülkenin yetki alanında vergileme ile ilgili olarak doğrudan veya dolaylı herhangi bir fiziki işyerine sahip olmayabilen deniz aşırı ülkelerdeki tedarikçilerden nihai tüketicilerin mal, hizmet ve gayri maddi varlık edinmesi durumunda varış ülkesinde KDV veya Satış Vergisi toplama zorluğu,

- Bazı işletmelerin, geçmişte daha az fiziki işyeri olan bir ülkedeki satışlardan gelir elde etme kabiliyetinin vergi yükümlülüklerinin belirlenmesinde

\footnotetext{
${ }^{1}$ Ekim/1998 döneminde Kanada'da gerçekleştirilen Ottawa Konferansı, vergilendirmeye yönelik çerçeve ilkeler ile elektronik ticaretin getirdiği vergilendirme sorunlarına yönelik bir uzlaşı getirilmesi amacıyla OECD üye ülke bakanları düzeyinde gerçekleştirilen bir konferanstır.
} 
fiziksel işyerinin varlığını dikkate alan mevcut kuralların uygunluğunun sorgulanmas1,

- Bazı işletmeler için verilerin toplanması ve izlenmesi de dâhil olmak üzere dijital ürün ve hizmetler için kullanıcılarının değer zincirindeki katkılarının yararlanmalarını ve bu katkıya nasıl atfedileceği ve değerlendireceği sorununu ortaya koyma kabiliyeti.

Birleşmiş Milletler de dijital ekonomide faaliyet gösteren işletmelerin, vergi planlama yapılarını, bunları üreten faaliyetlerden yapay olarak ayrıştırmak için kullanma firsatına sahip olmaları ve maddi olmayan duran varlıklara ve verilerin gelişmiş hareketliliğe ve küresel olarak entegre iş modellerine uygulanabilirliği nedeniyle dolaylı vergiler (KDV) açısından riskler taşıdığı üzerinde uzlaşmıştır (Li, 2014:27).

Dijital ekonominin vergilendirilmesi yönelik 1 Numaralı Eylemde tüketim yeri ilkesine hizmet teslimleri de dâhil edilerek, firmadan firmaya ve firmadan tüketiciye işlemlerde, tüketimin gerçekleştiği yerde vergilendirme yapılması yönünde adım atılmıştır (OECD, 2015).

Benzer şekilde Avrupa Birliği de ortak KDV sisteminde ulusal sınırlar aşan ticarette katma değerinde vergilendirileceği yer olarak hizmetin tüketildiği yeri kabul etmiştir (Gerger ve Gerçek, 2016).

Avrupa Birliği her ne kadar KDV tarhiyatı için tüketim yerini işaret etmiş olsa da birlik olma avantajını kullanarak Mini Tek Durak Noktası (Mini One Stop Shop) adı verilen bir sistemi hayata geçirmiştir. MOSS, Avrupa Birliği tarafından oluşturulmuş bir KDV sistemidir. $\mathrm{Bu}$ sisteme göre, mal ve hizmet tedariki sağlayanlar Avrupa Birliği üyesi ülkelerden herhangi birisinde MOSS'a kaydolabilmekte, üçer aylık dönemler itibariyle elektronik ortamda KDV beyanında bulunabilmektedirler. Toplanan katma değer vergisi MOSS'a aktarılmakta ve MOSS da bunları ilgili ülkelere elektronik ortamda transfer etmektedir. Bu sisteme dahil olmayan tedarikçiler ise hangi ülkeye mal ve hizmet sağlıyorlarsa doğrudan o ülkeye üçer aylık dönemler itibariyle KDV beyanında bulunup ödeme yapmaktadırlar. Ancak anlaş1lacağ 1 üzere söz konusu sistem gönüllü olarak kayıt olunarak işlemektedir (Ertaş, 2017a).

Başka bir açıklama ile Mini Tek Durak Noktası uygulaması, arz yeri kurallarının değiştirilmesi ile oluşturulmuş bir sistem olarak ifade edilebilmektedir. Elektronik ticaret, radyo televizyon yayıncılı̆̆ gibi işletmeden tüketiciye (B2C) sunulan hizmetlerden özel kişilere arz edilenlerin vergilendirilmesinde, tüketicinin yerleşik kabul edildiği üye ülke katma değer vergisi düzenlemeleri esas alınmaktadır. İşletmeden tüketiciye tedarikler ortaya çıkmadan önce, katma değeri vergilendirme yetkisi arz yer ülkesine ait bulunmaktayd. $\mathrm{Bu}$ durumda, Lüksemburg'dan tedarik edilen B2C hizmete \%15 KDV, Danimarka'dan tedarik edilen aynı hizmete ise \%25 KDV uygulanmaktaydı. Bunun yanı sıra, eğer B2C türündeki hizmet ABD'den tedarik ediliyor ise büyük bir problem ortaya çıkmaktaydı. Çünkü Amerikan hukuk sisteminde KDV uygulaması yer almamakta Genel Satış Vergisi (GST) uygulanmakta olduğundan, Amerika'dan sunulan bu hizmet bakımından bir vergilendirme yapılamamaktaydı. Bu tür elektronik olarak 
tedarik edilen hizmetlerin $\mathrm{AB}$ 'li tedarikçilerini korumak ve adil bir iç pazar oluşturabilmek adına arz yeri kuralını değiştirilmesi ve şimdi bu tür tedariklerin müşterinin ikamet ettiği üye ülkede yani tüketim yeri prensine göre vergilendirileceği kabul edilmiştir. Örneğin, eğer Belçika'da yaşıyorsanız, kimden veya nereden bu hizmeti sağladığınıza bakılmaksızın \%21 KDV oranı ile vergilendirilecektir. MOSS yukarıda sayılan hizmetleri sağlayan (elektronik ticaret, telekomünikasyon, radyo televizyon yayıncılı̆̆ı) tüm tacirlere sadece bir ülkede kayıt olma hakkı tanımaktadır. Bu şekilde örneğin, bir Amerikalı şirket bir üye ülkede kayıt altına alınacak ve tüm Avrupa'ya ticaret yapmak için her bir üye ülke için ayrı ayrı KDV numarası almak yerine bir tek KDV numarası edinerek beyanname verebilecek ve bir vergi idaresi ile muhatap olarak vergisel yükümlülüklerini yerine getirebilecektir (Kurt ve Ubay, 2014:22).

KDV açısından sadeleşmiş bir uyum rejimi olan MOSS uygulaması ile Avrupa Birliği 2015 yılında 3 milyar avro katma değer vergisi tahsil etmiştir (Deloitte 2016;16). Ayrica OECD tarafından dijital ekonominin vergilendirilmesi üzerine 16 Mart 2018 tarihinde hazırlanan geçici raporda da MOSS uygulamasını benimseyen işletmelerin uyum yükünün kayda değer oranda azaldığ belirtilmektedir (OECD, 2018;122).

\section{3065 sayılı Katma Değer Vergisi Açısından Dijital Ekonomi}

3065 Sayılı Katma Değer Vergisi Kanunu' ${ }^{21}$ 'nun 1. Maddesi'nde Türkiye'de yapılan ticari, sınai, zirai ve serbest meslek faaliyeti kapsamındaki teslim ve hizmetlerin KDV kapsamında olduğu belirtilmiştir. İşlemin Türkiye'de yapıldığının kabulü ise hizmetler açısından aynı Kanun'un 6/b. Maddesi'nde Türkiye'de ifa edilmiş olması veya hizmetten Türkiye'de faydalanılmasına bağlanmıştır.

Dijital ortamda yurt dışında bulunan kişi ve kurumlar hizmet üretimlerini Türkiye dışında gerçekleştirmektedirler. Örneğin reklam yayınlanmasını sağlayan bir arama motoru veya sosyal medya platformu operasyonunu yurt dişında yürütmektedir. Ancak bu kişi veya kurumlar Türkiye'de mukim kişi veya kurumlardan yine Türkiye'de yayınlanmak üzere reklam aldıklarında söz konusu reklamcılık hizmetinden yine Türkiye'de faydalanılmış olunmaktadır. Dolayısıyla ilgili Kanun maddesi gereğince hizmetten Türkiye'de yararlanıldığından işlemin Türkiye'de gerçekleşmiş olduğu kabul edilmektedir (Ertaş, 2017a).

Verginin kim tarafından beyan edileceği hususu ise aynı Kanun'un 9. Maddesinde yer verilmiştir. Türkiye'de işyeri, kanuni merkezi ve iş merkezi bulunmayanlardan alınan hizmetler dolayısıyla, alıcının sorumlu sifatı ile KDV beyanında bulunmasını gerekmektedir. Dolayısıyla yurt dışından alınan hizmetlerin KDV'sinin Türkiye'de beyan yolu ile vergilendirilmesi sistemi mevzuatımızda yer almaktadır (Alptürk, 2009). Söz konusu hizmetin internet üzerinden alınmış olmasının bu madde hükümlerinin uygulanmasına engel olmayacağı belirtilerek dijital mal ve hizmetler açısından uygulanmasının önü açılmıştır. 
Bu uygulama her ne kadar gerçek kişi ve kurum mükellefler tarafından uygulanabiliyor olsa da potansiyel mükellefler tarafindan uygulanmamaktadır, daha doğrusu bilinmemektedir. Hâlbuki sorumlu sıfatı ile beyanda bulunmak için KDV mükellefiyetliğinin olması şart değildir. Dolaysıyla yurt dışından hizmet alan herkes sorumlu sıfatı ile KDV beyanının muhatabıdır. Hizmeti üreten kişi veya kurumun yurt dışında olmasına rağmen hizmetten yurtiçinde faydalanıldığının tespiti halinde KDV'nin doğduğu açıktır. Ancak burada esas mesele verginin hangi tarafça ve nasıl en kolay şekilde beyan edilip ödeneceğidir (Nazali, 2018).

\section{D. Ülkemizde Dijital Ekonominin Vergilendirilmesi Adına Mevcut ve Yeni Yapılacak Düzenlemelerin KDV Bakımından Değerlendirilmesi}

Dijital ekonominin getirdiği vergilendirme sorunlarının giderilmesine yönelik Vergi Usul Kanunu Tasarısı'nda elektronik ortamda işyeri kavramına, işyeri oluşup oluşmaması hususuna açıklık getirilmesine ve Avrupa Birliği'nde 2015 y1lından itibaren uygulanan MOSS sistemi benzeri uygulamanın 7061 sayılı Kanun ${ }^{1}$ 'la getirilen ülkemiz uygulanmasına değinilecektir.

\section{Elektronik Ortamda İşyeri}

Yasalaşması için çalışmaları devam eden VUK tasarısında, elektronik ortamda işyeri kavramının da kullanılmıs olması, dijital ekonominin daha etkin vergilendirilmesi amacıyla uluslararası alanda yapılan çalışmaların bir sonucu olarak karşımıza çıkmaktadır. VUK'ta yapılması düşünülen ilgili değişiklikler KDV'yi beyan edecek taraflarnn tespiti konusuna da etki edecektir. Söz konusu Kanun tasarısının 130. maddesinde; internet, ekstranet, intranet ya da benzeri bir telekomünikasyon ortam veya aracının ticari, sınai veya mesleki faaliyete tahsis edilmesi veya bu faaliyetlerde kullanılması durumunda elektronik ortamda iş yeri oluşacağ 1 belirtilmiştir. Bununla birlikte taslağın 129. Maddesindeki işyeri kapsamına elektronik ortam da eklenmiştir (Budak, 2018:154). İşlemin taraflarının tespiti ve hangi ülkenin yargı alanı dahilinde olduğunun belirlenmesi uygulanacak KDV sistemini de olumlu etkileyecektir.

\section{2. İşyeri Oluşumu}

Elektronik ortamın işyeri kabul edilmediği mevcut yasal düzende, yurt dışından elektronik ortamda alınan hizmetlerin sorumlu sıfatı ile beyanında ise aşılması gereken önemli boyutta bir potansiyel mükellef sorunu vardır. KDV genel uygulama tebliğinin tam tevkifat uygulaması bölümünde "Genel bütçeli idareler dışındaki vergi sorumluları tevkif ettikleri vergiyi, vergi sorumlularına ait 2 No.lu KDV Beyannamesi ile beyan ederler. Bunların başka faaliyetleri nedeniyle KDV mükellefiyetlerinin bulunmaması ve dolayısıla 1 No.lu KDV Beyannamesi vermemeleri bu uygulamaya engel değildir." ifadelerine yer verilmiştir. Söz konusu ifadeler potansiyel mükelleflerin dahi sorumlu sıfatı ile KDV beyanında bulunması gerektiğini belirtmektedir. Aynı bölümde verilen örneklere bakıldığında ise acaba sorumluluk tüzel kişiliği olan ancak KDV mükellefiyeti olmayanları mı kastetmektedir sorusunu akıllara getirmektedir. Bu hususa açıklık getirilmesi gerektiği şarttır. Ancak sorumlu sıfatı ile beyan potansiyel mükellefleri kapsasa

\footnotetext{
${ }^{1}$ 28/11/2017 tarihli ve 7061 sayılı Bazı Vergi Kanunları İle Diğer Bazı Kanunlarda Değişiklik Yapılmasına Dair Kanun, (RG. 5.12.2017-30261).
} 
dahi, bunun uygulama da nasıl denetleneceği konusu ise en büyük soru işareti olacaktır (Y1lmaz, 2018).

Sorumlu sıfatı ile KDV beyanının yerine getirilmesinde diğer bir tereddüt ise farklı alanlar için kendi bünyesinde farklı şirketler kurmuş şirketlerin Türkiye'de işyeri olup olmadığı konusudur. Bu husus verginin kim tarafından beyan edileceği sorununu daha da ileri taşımaktadır. Şöyle ki; Merkezi ABD'de olan A Arama Motoru Inc. Türkiye'de kendi adıyla reklam pazarlama alanında bir şirket kurmuştur. Ancak aynı arama motoru reklam operasyonlarını yürütmek üzere İlanda' da başka bir şirket kurmuştur ve ödeme işlemleri, telefonla müşteri desteği dahil bu şirket üzerinden o ülkede yürütmektedir. Bu durumda ana şirketin Türkiye'de işyerinin olmasına rağmen vergilendirmeye konu operasyonun başka bir ülkeden idare edilmesinin vergi mükellefiyeti ve vergi sorumluluğu açısından karşı1ığının ne olacağı tartışmalıdır. Şirket Türkiye'de işyeri olmasına rağmen vergilendirmeye konu işlemin yurt dışından yönetildiğini iddia edebilecektir. Hizmetten Türkiye'de faydalanan kişi ve kurumlar ise aynı tespitten hareketle vergi beyanın kim tarafından yapılacağı tereddüdünü yaşayacaktır. Dolayısıyla KDV'de tam tevkifat uygulamasında dikkate alınan "işyeri, kanuni merkezi ve iş merkezi" kavramlarının ne ifade ettiği de ayrıca açıklığa kavuşturulmalıdır (Ertaş, 2017a).

\section{Değiş̧ikliği}

3. 7061 sy. Kanun ile Yurtdışından Alınan Hizmetlerde KDV

5 Aralık 2017 tarihinde 30261 sayılı Resmî Gazetede yayımlanarak yürürlüğe giren 7061 sayılı Kanun 41. madde ile 3065 sayılı Katma Değer Vergisi Kanununun vergi sorumlusu başlıklı 9 uncu maddesinin 1 numaralı fikrasına aşağıdaki cümleler eklenmiştir.

'Şu kadar ki Türkiye'de ikametgâhı, işyeri, kanuni merkezi ve iş merkezi bulunmayanlar tarafından katma değer vergisi mükellefi olmayan gerçek kişilere elektronik ortamda sunulan hizmetlere ilişkin katma değer vergisi, bu hizmeti sunanlar tarafından beyan edilip ödenir. Maliye Bakanlığı elektronik ortamda sunulan hizmetlerin kapsamı ile uygulamaya ilişkin usul ve esasları belirlemeye yetkilidir."

Bu değişiklikle birlikte Avrupa Birliğinde 2015 y1lında uygulamaya giren MOSS uygulaması benzeri bir sistem ülkemizde de kabul edilmiştir. KDV mükellefiyeti olmayan gerçek kişilerin yani nihai tüketicilerin, Türkiye'de ikametgâhı, işyeri, kanuni merkezi ve iş merkezi bulunmayanlardan elektronik ortam üzerinden hizmet almaları halinde KDV, hizmeti sunanlar tarafindan beyan edilip ödenecektir (Ertaş, 2017c). Somut bir örnek vermek gerekirse, takipçilerini çoğaltmak isteyen ve KDV mükellefiyeti bulunmayan bir kişi Instagram'a reklam vermesi halinde, Merkezi ABD'de bulunan ve Türkiye ile hukuki olarak hiçbir bağ olmayan Instagram'dan hizmetin KDV'sini beyan edip ödenmesi beklenecektir (Ertaş, 2017b).

Daha önceki düzenlemede yurt dışından alınan hizmetler için KDV'nin 9. Maddesinde şu ifadeler yer alıyordu “...mükellefin Türkiye içinde ikametgâhının, işyerinin, kanunî merkezi ve iş merkezinin bulunmaması hallerinde .... vergiye tabi işlemlere taraf olanları verginin ödenmesinden sorumlu tutabilir”. Söz konusu 
hüküm, Türkiye ile hukuki hiçbir bağ 1 bulunmayan kişilerden hizmet alınması halinde doğacak vergi, KDV mükellefi olup olmadığına bakılmaksızın hizmeti alan tarafından beyan edilip ödeneceğini ifade etmekteydi. Örnek ile açıklanırsa, takipçilerini çoğaltmak isteyen bir kişi, Instagram'dan aldığ 20 TL'lik reklam hizmeti için 2.No.lu KDV beyannamesi vermek ve vergiyi ödemekle mükellef olmaktaydı. Ancak bu durumda mükellef konumunda olanların sorumluklarından bihaber olmaları, tespit edilmeleri ve denetiminin neredeyse imkânsız olması KDV açısından vergi kaybı oluşturmaktaydı. Çünkü KDV mükellefi olmayanlar bir kenara mükellef olanların dahi yurt dışından alınan elektronik hizmetler için KDV sorumluluğunu yerine getirme konusunda tereddütler yaşadığı görülmektedir. Bu bağlamda KDV mükellefi olmayanları böyle bir beyan ve vergi ödeme yükümlülüğünden kurtarmak adına hizmeti sunan kişilerin sorumlu tutulmasına yönelik düzenleme yapılmış bulunmaktadır (Ertaş, 2017c).

Ancak bu düzenleme ile Türkiye'de ikametgahı, işyeri veya kanuni temsilcisi olmayan kişilere beyan ve vergiyi ödeme yükümlülüğü nasıl uygulatılacak sorusu ortaya çıkmaktadır. Bu sorunun yanıtına da Katma Değer Vergisi Genel Uygulama Tebliğinde Değişiklik Yapılmasına Dair Tebliğ ${ }^{1}$ ile yabanc1 elektronik hizmetlerde KDV beyanı ve ödenmesi konusu güncellenerek açıklık getirilmiştir. Tebliğde, Türkiye'de ikametgâhı, işyeri, kanuni merkezi ve iş merkezi bulunmayıp, belirtilen elektronik hizmetleri, katma değer vergisi mükellefi olmayan gerçek kişilere bir bedel karşılığında sunanların, bu hizmetlere ilişkin KDV'yi, “Elektronik Hizmet Sunucularına Özel KDV Mükellefiyeti” tesis ettirmek suretiyle beyan edecekleri belirtilmiştir. Söz konusu hizmet sunucularının, bu işlemlere ilişkin KDV'yi, 3 No.lu KDV beyannamesi ile elektronik ortamda beyan edecekleri ifade edilmiştir. Bu kapsamdaki hizmet sunucularının, ilk kez verecekleri 3 No.lu KDV beyannamesini, vermeden önce Gelir İdaresi Başkanlığının www.digitalservice.gib.gov.tr adresinde yer alan formu doldurmaları gerekmektedir. $\mathrm{Bu}$ formun elektronik ortamda doldurulup onaylanması üzerine Büyük Mükellefler Vergi Dairesi Başkanlığı nezdinde, hizmet sunucusu adına "Elektronik Hizmet Sunucularına Özel KDV Mükellefiyeti" tesis ettirilmektedir (Ertaş, 2017b).

$\mathrm{Bu}$ düzenlemeler etkisini hemen gösterdiği görülebilmektedir. Online perakende devi Amazon, ülkemizdeki yeni vergi düzenlemesi sonrası Türkiye'den yapılan alışverişler için yeni KDV sistemine geçiş yaptığını duyurmuştur. Müşterilerden bir an önce vergi numaralarını sisteme girmelerini talep eden şirket, satılan her ürüne otomatik olarak \%18 KDV ekleyeceğini bildirerek ilk adımı atmıştır (Baltaş, 2018). Amazon'un üyelerine gönderdiği bilgilendirme e-postası;

"1 Haziran 2018 tarihinden itibaren geçerli olmak üzere Amazon Web Services, Inc. ve AWS Marketplace, faturalandırma adresi Türkiye ("TR") olan müşterilerden, bir işletme olarak işlem yapmadıkça ve geçerli bir Türkiye Vergi

\footnotetext{
${ }^{1}$ Katma Değer Vergisi Genel Uygulama Tebliğinde Değiş̧iklik Yapılmasına Dair Tebliğ (Seri No: 17), (RG. 31.1.2018- 30318).
} 
Kimlik Numarası ("TIN") sağlamadıkları sürece, AWS Marketplace'de satılan ürünler de dahil olmak üzere, bütün satın alımlarda \%18 Katma Değer Vergisi ("KDV") talep edecektir."

Yukarıda değindiğimiz üzere 1 Ocak 2018 tarihi itibariyle yürürlüğe giren Katma Değer Vergisi Kanunu'nun 9. maddesinin 1. fikrasında yapılan değişiklik ile, Türkiye'de vergi mükellefiyeti olmayan kişilere sunulan elektronik hizmetlerin konusunu oluşturduğu katma değer vergisini beyan edip ödeme yükümlülüğünü, hizmeti sunanların yerine getirilmesine hükmedilmiştir. Amazon şirketinin, müşterilerinin T. C. kimlik numaralarını isteyerek mükellefiyeti olmayan kişilere vermiş oldukları dijital hizmetlere yönelik katma değer vergisini hizmet fiyatlarına ekleyerek tahsil edeceği anlaşılmaktadır. Ancak Google, reklam hizmetleri ayağını oluşturan Adwords hizmetini kullananları kendi nezdinde ticari hesaplar olarak nitelendireceğini belirtmiştir. $\mathrm{Bu}$ durum ise ticari olarak Adwords hizmetini kullananların yanında mükellefiyet kaydı bulunmayan kişilere sunduğu hizmetler için de katma değer vergisi beyanı ve ödemesi gerçekleştirmeyeceğini ifade etmektedir. Google'ın nasıl nitelendirdiğinden ziyade ülkemiz KDV mevzuatı doğrultusundan nasıl değerlendirileceği önem arz etmektedir. Ancak Adwords hizmetinden yararlanan ve vergi mükellefiyeti olmayanlar için doğacak katma değer vergilendirilmemiş olacaktır. Amazon gibi katma değerin beyan ve ödenmesi yükümlülüğünü üstlenen aracı kurumlar olabileceği gibi Google gibi katma değerin vergilendirilmesi açısından sorumlu olmadığını belirten yerleşik olmayan aracı kurumlar da olabileceğinden dijital hizmetlerin sunumundan doğan katma değerin tespit ve tahsilinde kayıplar yaşanabilecektir (Ertaş, 2018).

\section{SONUÇ}

Mal ve hizmet sunumunun dijital ortamda gerçekleştirilebilmesi ile katma değer vergisi açısından olayların değerlendirilmesi ihtiyacı doğmuştur. Fiziki varlığa sahip olup dijital platformlar aracılığıyla sunulan mallarda katma değer vergisi açısından mevcut kurallar yeterliliğini korumaktayken, dijital olarak sunulan mal ve hizmetlerin tedarik aşamalarının kavranması ve vergilendirmesinde mevcut katma değer vergisi kurallarının yetersiz kaldığı görülmektedir. Özellikle yerleşik olmayan yurtdışı işletmeler tarafindan gerçek kişilere sunulan hizmetlerde, KDV açısından sorumlu olan bu gerçek kişilerin sorumluluklarını yerine getirmedikleri ve vergi kayıplarına neden oldukları söylenebilir. Bu sorunun ana nedenleri; mükellefiyet tesis ettirme ve beyanname verme koşullarının zor olması, ödeyecekleri katma değer vergisini indirim mekanizmasından faydalanarak indiremeyecekleri için aldıkları hizmetin maliyetini arttırması, tespitinin ve denetim geçirme ihtimalinin çok az olması gibi durumlardan oluştuğu belirtilebilir. $\mathrm{Bu}$ nedenlerle birlikte dijital ekonomi ile nihai tüketicilere yani gerçek kişilere sunulan mal ve hizmetlerin artması, KDV açısından yaşanan gelir kaybının giderek artacağı anlamına geleceğinden gerekli çalışma ve önlemlere duyulan ihtiyacı ortaya koymaktadır.

Bunlara ek olarak, dijital ürünlerin niteliğinin belirlenememesi yani ürünlerin karakterinin hizmet olarak $\mathrm{m}$, yoksa mal olarak $\mathrm{m} 1$ değerlendirileceği, gayri maddi hak kapsamına girip girmeyeceğinin tespit edilmesi, bu ürünlerin 
satışından elde edilecek gelirin hangi kazanç kapsamına gireceği konusunda sorunların var olduğu görülmektedir. Dolayısıyla ne şekilde vergilendirileceği bilinmeyen ve tespiti zor olan bir alım satım işleminden elde edilen katma değerin vergilendirilmesi de güçleşecektir.

Ekim 1998 tarihinde Ottawa Konferansı ile ilk olarak elektronik ticaretin ortaya çıkardığı sorunlara yönelik önerilerle başlayan uluslararası çalışmalar, dijital ekonominin getirdiği vergilendirme sorunlarının değerlendirilmesine yönelik yine 2015 yılında G20 ülkelerinin iş birliği ile OECD tarafından hazırlanan Matrah Aşındırma ve Kar Aktarımına yönelik eylem planı ile devam etmiştir. Bu çalışma ile ülkelerin vergi gelirlerini azaltan dijital ekonominin getirdiği öncelikli sorunların ve işlemlerin tespiti ve tanımlamasının yapılması gerektiği belirtilmiştir. Katma değerin vergilendirilmesinde ortaya çıkan sorunların, dijital ekonominin vergilendirmeyi etkileyen özelliklerinden olan gayri maddi varlıkların hareketliliği ve fiziki işyeri olmaksızın gerçekleştirilebilen yurtdışı hizmet sunumuna yönelik sorunların üzerinde durularak, öneriler getirilmiştir. Birleşmiş Milletler 'in, OECD tarafından sunulan BEPS Eylem Planı'nı benimsemesi yapılan çalışmalarda görüş birliğini oluşması ve çözümlerin etkili olmasını arttıracağı söylenebilir. Avrupa Birliğinin de Birlik içerisinde katma değer vergisi uygulamasına yönelik getirdiği ve arz yeri kurallarının değiştirilmesi ile oluşturduğu MOSS sistemi ile önemli adımlar attığı söylenebilir.

Ülkemizde de dijital ekonomi ile elde edilen katma değerin vergilendirilmesine yönelik AB'nde uygulan MOSS sistemi benzeri uygulamaya geçileceği 7061 sayılı Kanun ile kararlaştırılmıştır. Bu kanuna göre, yerleşik olmayan yurtdışı işletmeler tarafından elektronik ortam aracılığıyla Türkiye'deki gerçek kişilere sunulan hizmetlere ilişkin katma değer vergisinin, bu hizmetleri sunanlar tarafından beyan edilip ödeneceği belirtilmiştir. Önemli bir gelişme olmakla birlikte tereddütler barındırdığını da belirtmekte fayda bulunmaktadır. Şöyle ki, Türkiye ile hiçbir bağı olmayan bu işletmelerin hukuki yollarla verginin beyanına ve ödenmesine zorlamanın mümkün olup olmadığ 1 tartışmalıdır. Katma değerin vergilendirilmesinde uluslararası genel kabul görüş olan, ürünün teslim edildiği veya hizmetin yapıldığı, faydalanıldığ vergilendirildiği görüşü ile paralellik arz etmesine rağmen, kişi veya kurumların vergi ödemeye mecbur kılınması için onlar üzerinde bir egemenlik sahibi olunmadığı da açıktır. Bu durumda verginin beyan ve ödenmesinin sağlanması için yaptırımı olan uluslararası anlaşmaların olması gerektiği ihtiyacı ortaya çıkmaktadır.

Yapılan düzenlemeler dahilinde nispeten olumlu adımlar atıldığ 1 söylenebilir. Ancak dijital ekonominin dinamik yapısı, kapsamı altındaki birçok faaliyete yönelik boşluk ve belirsizlik oluşturmaktadır. Google'ın Adwords hizmetlerine yönelik tutumunu benimseyen dijital hizmet sunucuları olabileceğinden, vergi mükellefiyeti tesis ettirme zorunluluğu olmayan ancak bu hizmetlerden yararlanan kişilerin kullandığı hizmetlerden doğan katma değer vergisinin sorumluluğu ortada kalmaktadır. 
Bu gibi sorunlar ve farklı uygulamaların ortaya çıkmasını mümkün kılan sanal ortam vergi kayıplarına neden olabilecektir. Dolayısıyla vergi gelirlerinde azalma yaşayacak ülkelerin, vergilendirmede oluşabilecek yeni sorun ve boşlukları önlemek için vergi sistem ve yapılarını dijitalleşme süreci ile paralel işleyecek şekilde planlamaları gerekmektedir. Vergi sistem ve yapılarının hantallığı, fiziki evraklar üzerinden yürütülen işlem ve süreçler her gün yeni iş olanağ1 doğuran dijital çağa ayak uydurmakta zorlanmaktadırlar. Vergi dairelerinde mali mevzuata hâkim yeni nesil çalışanların yanında bilgisayar, bilişim ve yazılım mühendislerinin sayılarının daha da arttırılması ile ve dijital ekonominin vergilendirilmesine yönelik yasal ve sistemsel zeminin oluşturulması hedefi ile çalışmalar yapılarak en azından dijital çağın takibi mümkün olabilecek ve dijital ekonomiye yönelik olarak vergi sistem ve yapıları kendilerini güncelleme imkânı bulabileceklerdir.

\section{KAYNAKÇA}

Aktaş, H. (2010). İnternet Reklam Türlerinde Uygulayıcılardan Kaynaklanan Sorunlar ve Bir Sınıflandırma Önerisi. Selçuk Üniversitesi İletişim Fakültesi Akademik Dergisi 6(3), 147166.

Alptürk, E. (2005). Elektronik Ticaretin Hukuku Ve Vergilendirilmesi. İstanbul: Gelirler Kontrolörleri Derneği.

Alptürk, E. (2009). Elektronik Ticarette KDV Sorunlar1. https://www.xing.com/communities/posts/elektronik-ticarette-kdv-sorunlari-1005029461, (Erişim Tarihi: 07.05.2018).

Baltaş, R. (2018, Mayıs 6). Amazon Alışverişlerine \%18 KDV Geliyor. https://www.technopat.net/2018/05/06/amazon-alisverislerine-kdv-geliyor/, (Erişim Tarihi: 07.05.2018).

Bayraç, H. N. (2003). Yeni Ekonomi'nin Toplumsal, Ekonomik Ve Teknolojik Boyutları. Osmangazi Üniversitesi Sosyal Bilimler Dergisi, 4(1), 22.

Belleflamme, P., Toulemonde, E. (2016). Tax Incidence on Competing Two-Sided Platforms: Lucky Break or Double Jeopardy. SSRN Scholarly Paper No. ID 2777364, Social Science Research, Rochester NY, https://papers.ssrn.com/abstract=2777364.

Budak, T. (2018). Dijital Ekonominin Vergilendirilmesi, İstanbul: On İki Levha.

Charrié, J., Janin, L. (2015) Taxation of the digital economy. La Note D'analyse, (26), 8.

Coşkun, N. (2005). Elektronik Ticarette Vergilendirme Sorunları ve Uluslar Arası Düzeyde Çözüm Arayışlarının Türkiye Açısından Değerlendirilmesi. Çukurova Üniversitesi Sosyal Bilimler Enstitüsü Dergisi, 14(1), 153-170.

Deloitte (2016). VAT Aspects of cross-border ecommerce - Options for modernisation Final reportLot 3. https://ec.europa.eu/taxation_customs/sites/taxation/files/vat_aspects_crossborder_e-commerce_final_report_lot3.pdf. (Erişim Tarihi: 18.07.2019).

Gerger, G. Ç., Gerçek, A. (2016). Elektronik Ticaretin Vergilendirilmesi Açısından Katma Değer Vergisinin Uygulama Sorunlarının Değerlendirilmesi. International Journal of Public Finance, 1(1), 61-74.

Elele, O. (2016). 3D Yazıcılar ile Üretimin İçerdiği Vergi Riskleri. http://www.onurelele.net/?p=404, (Erişim Tarihi: 08.04.2018).

Elele, O. (2018). İnternette Freelance Çalışanlar ve Çalıştıranların Vergilemesi. https://www.ey.com/tr/tr/services/tax/dijital-vergi-freelance-calisanlarin-vergilemesi, (Erişim Tarihi: 03.06.2018).

Eralp, Ö. E. (2018, Şubat 8). Freelance Çalışanların Vergilendirmesi Ile İlgili Merak Edilenler. http://www.bookmark.com.tr/freelance-calisanlarin-vergilendirmesi-ile-ilgili-merakedilenler/, (Erişim Tarihi: 03.06.2018).

Ertaş, B. L. (2017a). Dijital Ekonomide Yurt Dışından Alınan Hizmetler Bakımından Kdv Mevzuatındaki Sorunlar. Vergi Raporu Mevzuat Dergisi, (219), 10. 
Ertaş, B. L. (2017b, Aralık 6). Yurtdışından Alınan Elektronik Hizmetler İçin Yeni KDV Uygulaması. http://bilallevent.com/yurtdisindan-alinan-elektronik-hizmetler-icin-yeni-kdvuygulamasi.html, (Erişim Tarihi: 07.05.2018).

Ertaş, B. L. (2017c, Aralık 27). Yabancı Elektronik Hizmetlerde KDV Beyan ve Ödeme Tebliğ Taslağı. http://bilallevent.com/yabanci-elektronik-hizmetlerde-kdv-beyan-ve-odemeteblig-taslagi.html, (Erişim Tarihi: 07.05.2018).

Ertaş, B. L. (2018, Kasım 15). Adwords Ödemelerinde KDV Mevzusu. http://bilallevent.com/adwords-odemelerinde-kdv-beyan-mevsuzu/, (Erişim Tarihi: 20.12.2018).

France Stratégie (2015). Taxation and the Digital Economy: A Survey of Theoretical Models. Toulouse School of Economics, 57.

Kızıl, C. (2016). Web Sitesi Ve İnternet Maliyetlerinin Türkiye Muhasebe Standartlarına Göre Muhasebeleştirilmesi. Kesit Akademi Dergisi, Baskı Yıl1:2(6), 106-121.

Kurt, A., Ubay, B. (2014, Mayıs). .Vergilendirme Bülteni. Gelir İdaresi Başkanlığ Vergilendirme, (Özel Sayı), 34.

Li, J. (2014). Protecting the Tax Base in the Digital Economy. United Nations Paper, (9), 49.

Nazali, E. (2018, Nisan 17). Elektronik Ortamda Sunulan Hizmetlerde Yeni KDV Rejimi. http://www.mondaq.com/turkey/x/692556/sales+taxes+VAT+GST/Elektronik+Ortamda+ Sunulan+Hizmetlerde+Yeni+KDV+Rejimi, (Erişim Tarihi: 10.05.2018).

OECD (2015). Addressing the Tax Challenges of the Digital Economy, Action 1 - 2015 Final Report. Paris: OECD Publishing. http://dx.doi.org/10.1787/9789264241046-en, (Erişim Tarihi: 09.04.2018).

OECD (2017). International VAT/GST guidelines. Paris: OECD Publishing. https://read.oecdilibrary.org/taxation/international-vat-gst-guidelines_9789264271401-en\#page1, (Erişim Tarihi: 07.05.2018).

OECD (2018). Tax Challenges Arising from Digitalisation -Interim Report 2018. Paris: OECD Publishing. $\quad$ https://read.oecd-ilibrary.org/taxation/tax-challenges-arising-fromdigitalisation-interim-report_9789264293083-en\#page1, (Erişim Tarihi: 18.07.2019).

Olbert, M., Spengel, C. (2017). International Taxation in the Digital Economy: Challenge Accepted? http://www.austaxpolicy.com/international-taxation-digital-economy-challenge-accepted/ (Erişim Tarihi: 06.04.2018).

Organ, İ., Çavdar, F. (2012). Problems in the international field of taxation of electronic commerce. Journal of Internet Applications and Management, 3(1), 63-84.

Özcan, P. M. (Ekim 2016). Dijital Ekonominin Vergilendirilmesinde Karşılaşılan Sorunlar: Beps 1 No'lu Eylem Planı Kapsamında Bir Değerlendirme. Electronic Journal of Vocational Colleges. http://www.ejovoc.org/makaleler/october_2016/pdf/07.pdf, (Erişim Tarihi: 13.03.2018).

Özen, Ü., Sarı, A. (2008). İnternet Reklamcılığı: İnternet Kullanıcılarının İnternet Reklamcılığı Konusundaki Tutum ve Davranışları. Bilişim Teknolojileri Dergisi, 1(3), 12.

Topuz, G. (2017, Haziran 19). Dijital Ekonomide Vergileme Tercihleri ve Türkiye: Ne Tür Bir "İnternet Vergilemesi"?. http://gorkemtopuz.com/dijital-ekonomide-vergileme-tercihlerive-turkiye-ne-tur-bir-internet-vergilemesi/, (Erişim Tarihi: 07.05.2018).

World Bank (2016). World Development Report 2016: Digital Dividends. http://www.worldbank.org/en/publication/wdr2016, (Erişim Tarihi: 14.04.2018).

Yılmaz, G. H. (2018). Dijital İktisadi Faaliyetlerde İşyeri Paradoksu ve Vergisel Boyutu. http://www.verginet.net/dtt/18/DijitallktisadiFaaliyetlerdeIsyeriParadoksuveVergiselBoyu tu.aspx, (Erişim Tarihi: 11.04.2018).

\section{SUMMARY}

As the delivery of goods and services can be realized in digital environment, it is necessary to evaluate the events in terms of value added tax. It is seen that the current value added tax rules are inadequate in understanding and procuring the supply stages of digital goods and services while preserving the 
existing rules in terms of value added tax in the goods which have physical existence and are presented through digital platforms. It may be said that these real persons, who are responsible for VAT, do not fulfill their responsibilities and cause problems, especially in services provided by foreign enterprises that are not resident in real persons. The main reasons for this problem are; it can be stated that the conditions for establishing liability and declaration are difficult, the cost of the service they get because they will not be able to deduct the value added tax due to the deduction mechanism, and there is little possibility of detection and inspection. Along with these reasons, the increase of the digital economy and the final consumers, that is, the goods and services offered to the real persons, means that the loss of income in terms of VAT will increase gradually, thus revealing the need for necessary studies and precautions.

In addition to these, it can be said that the quality of the digital products can not be determined; that the characteristics of the products are considered as services or goods, whether they are within the scope of intangible rights, and the income from the sale of these products. It will therefore become difficult to tax the value added in a trade that is difficult to determine and taxable.

In October 1998, the Ottawa Conference first started with proposals for the problems that emerged in electronic commerce and continued with the G20 countries' business association and OECD's Base Erosion and Profit Shifting Action Plan for the assessment of the taxation problems brought by the digital economy. It is stated that the priority problems and transactions brought by the digital economy which reduces the tax incomes of the countries should be identified and defined. Suggestions have been put forward, focusing on the mobility of intangible assets, one of the important features of digital economy's taxation that affects the taxation of value added, and the problems of providing foreign service without the physical workplace. It can be said that the United Nations' adoption of the BEPS Action Plan, which is presented by the OECD, will increase the influence of the formation of a consensus and solutions. It can be said that the European Union has taken important steps with the MOSS system which is created by applying the value added tax in the Union and by changing the rules of the place of supply.

In our country, it is decided by Law No. 7061 that the application of the MOSS system similar to that applied in the EU for the taxation of the added value obtained by the digital economy. According to this law, through the electronic media by non-resident overseas business of value-added tax on services provided to real people in Turkey, it shall be declared by those who provide these services are indicated. It is worth noting that there is doubt as well as a significant improvement. Namely, there is no legal way to look at the non-declaration of tax by these enterprises in Turkey and force the payment is debatable whether it is possible. It is also clear that, although taxation of value added is parallels with the view of the international general acceptance opinion, the product is delivered or the service is made, the place where it is used and taxed, it is obvious that no person or institutions have a dominance over them in order to force them to pay taxes. In this 
case, there is a need for international agreements to be sanctioned in order to ensure that the taxpayer is represented and paid.

It can be said that relatively positive steps have been taken within the regulations. However, the dynamic nature of the digital economy constitutes a gap and uncertainty for many activities under its scope. Since Google may be a digital service provider adopting its attitude towards Adwords services, it is the responsibility of the person who is not obliged to establish a tax liability, but is responsible for the value-added tax arising from the services used by those benefiting from these services.

Such problems and the virtual environment that enables the emergence of different applications can cause tax losses. Therefore, in order to avoid new problems and gaps in taxation, the countries that will experience a reduction in tax revenues should plan their tax systems and structures in a way that works in parallel with the digitalization process. The cumbership of tax systems and structures, and the processes and processes carried out on physical documents are challenging to keep up with the digital age that creates new jobs every day. Tax systems and structures for the digital economy can be carried out with the aim of creating a legal and systematic ground for the taxation of digital economy and further increasing the number of computer, informatics and software engineers in addition to the new generation employees who are in charge of financial legislation in the tax offices and they will be able to update tax systems. 